\title{
PROBLEMS IN VIETNAMESE-ENGLISH TRANSLATION OF RELATIVE CLAUSES FOR ENGLISH-MAJORED JUNIORS AT TAY DO UNIVERSITY, VIETNAM
}

\author{
Thi Bao Dung Dang, \\ Van Lanh Le, \\ Van Si Vo, \\ Phuong Nhu Nguyen, \\ Nhu Ngoc Hua \\ Faculty of Linguistics and Literture, \\ Tay Do University, \\ Can Tho City, Vietnam
}

\begin{abstract}
:
Realistically, Vietnamese-English translation is not easy for Vietnamese students to master, and relative clauses are not typical in Vietnamese. Therefore, learners cannot avoid mistakes in their translation practice. Concerned researchers carried out a study to identify common Vietnamese-English translation errors in terms of English relative clauses. The participants were 60 juniors from the Bachelor of English course at Tay Do University. Test papers and interviews were employed as the instruments. The collected data from the two instruments mentioned above were all analyzed carefully afterward. The results of the study showed that the students suffered from a variety of grammar and vocabulary problems hindering them from translating Vietnamese into English correctly.
\end{abstract}

Keywords: Vietnamese, English, translation, relative clauses

\section{Introduction}

Language is an integral factor in many aspects of our lives. Indeed, people cannot communicate with each other without language. It builds a bridge between people from different nations. However, language can be a barrier to communication because of the linguistic and cultural diversities of the world. In this case, translation bridges the gaps between people from other parts of the world, together with its interpretation.

It is obvious that translation is one of the factors that removes language obstacles and makes people closer. As a result, accurate and successful translation plays a pivotal role in effective communication. No one can deny the significance of the practice of

i Correspondence: email lvlanh@tdu.edu.vn 
translation in the universalization of human knowledge. It is considered as a form of communicating thoughts among various cultures. According to Roxana (2016), "communication between cultures can be achieved through translation. Through translation, people are introduced to different languages and ways of thought. It is important to understand the relation between language and culture in order to train translators and interpreters". Susan Bassnett (2014) also stated that "translation makes available material across a whole range of cultural activities that would otherwise be inaccessible to anyone who does not have access to other languages".

In Vietnam, people are more concerned about the quality of the translation field, especially Vietnamese-English translation. However, it is not easy for Vietnamese students to master this field because of the grammar and syntax differences. In English grammar, relative clauses are very complicated and have many rules to follow. CelceMurcia and Larsen Freeman (1999) claimed that "the acquisition of relative clauses is important because of their complex form and function, and high frequency in both spoken and written texts". Nonetheless, it is difficult to translate Vietnamese sentences into English relative clauses because relative pronouns do not exist in Vietnamese grammar. According to Dinh Van Duc (2001), "In Vietnamese we do not have the concept of "relative pronouns". Only the definition of pronoun exists".

In conclusion, Vietnamese learners often encounter difficulties in translating Vietnamese sentences into English relative clauses due to the non-existence of relative clauses in Vietnamese grammar.

This research was expected to discover translation problems that English-majored juniors at Tay Do University face in translating Vietnamese sentences into English relative clauses.

In furtherance of this aim, this research sought to address the following question:

- What are some problems confronted by English-majored juniors at Tay Do University in translating Vietnamese sentences into English relative clauses?

\section{Literature review}

\subsection{Definitions of translation}

Due to its prominence, the term "translation" has been defined by different authors. This has resulted in a considerable number of definitions describing the term, some of which are mentioned below. It can be said that translation is a process and a product. Catford (1995) defined that "translation is the replacement of textual material in one language (SL) by equivalent textual material in another language (TL)". Another author, Bayu Nugroho, (2007) gave a different definition of translation, describing it as "a process of rendering meaning, ideas, or messages of a text from one language to other language". There are some considerations following this process, which mainly relate to the accuracy, clarity and naturalness of the meaning, ideas, or messages of the translation. This leads to the fact that it is important to consider whether the readers of the target text accept equivalent information as the readers of the source text do. Additionally, Bui Tien Bao and Dang 
Xuan Thu (1997) pointed out another interesting definition, "it is rendering a written text into another language in the way that the author intended in the text". Nida and Taber (1982), on the other hand, elaborated that "translating consists in reproducing in the receptor language the closest natural equivalent of the source language message". In general, the purpose of translation is to reproduce various kinds of texts, including religious, literary, scientific, and philosophical texts, in another language and thus making them clear to wider readers. "Translation is the expression in another language (or target language) of what has been expressed in another, source language, preserving semantic and stylistic equivalences" (Marlone, 1988).

\subsection{Relative clauses}

\subsubsection{Definitions of relative clauses}

According to Celce-Murcia and Larsen Freeman (1999), "relative clauses are defined as a type of complex postnominal adjectival modifier that is used in both written and spoken English". Avery Andrew (2009) stated that "relative clauses are subordinate clauses that help to delimit the potential reference of a noun phrase (the relative clause says something that has to be true of anything that the noun phrase might refer to)". Similarly, Radford (2004) and Ballard (2007) claimed that "relative clauses are finite subordinate clauses that postmodify and identify or give extra information to their antecedents, i.e. noun phrases (NPS) and some pronouns. A relative clause is normally headed by a relativizer - for example 'who', 'which' or 'that', which refers back to the preceding NP or the antecedent in the main clause".

A relative clause is a clause that usually modifies a noun or noun phrase and is introduced by a relative pronoun (which, that, who, whom, whose), a relative adverb (where, when, why), or a zero relative. It is also known as an adjective clause, an adjectival clause, and a relative construction. According to Quirk (1985), "An adjective clause is introduced or marked by a relative pronoun, which can function as a subject, direct object, indirect object, object of the preposition, predicate noun or possessive determiner of an adjective clause and has co-reference to the antecedent".

\subsection{Types of relative clauses}

According to Garant (1991), there are two main types of relative clause: Restrictive relative clauses and Non-restrictive relative clauses. Marinet (2003) presented two basic types of relative clauses: defining relative clauses and non-defining relative clauses.

- Defining relative clauses (Restrictive relative clauses)

A defining relative clause gives essential information about the noun or noun phrase it modifies; the purpose of a defining relative clause is to clearly define who or what we are talking about. Without this information, it would be difficult to know who or what is meant. Obviously, this is only necessary if there is more than one person or thing involved.

- Non-defining relative clauses (Non-restrictive relative clauses) 
A non-defining relative clause provides interesting additional information that is not essential to understanding the meaning of the sentence. It tells us more about someone or something, but does not define it.

\subsection{Common problems in translating with relative clauses}

According to the American Translation Association (ATA) (2009), these include 22 types of errors: (1) incomplete passages, (2) illegible handwriting, (3) misunderstanding of the original text, (4) mistranslation into the target language, (5) addition or omission, (6) terminology/word choice, (7) register, (8) too freely translated, (9) too literal/word-forword translation, (10) false cognate, (11) indecision in word choice, (12) inconsistent, (13) ambiguity, (14) grammar, (15) syntax, (16) punctuation, (17) spelling, (18) accents and other diacritical marks, (19) case (upper case/ lower case), (20) word form, (21) usage, and (22) style.

However, some improvements have been made to the original material in order to have the best adapted criteria used in this study. Below are problems that students often face in English relative clauses translation:

\section{a. Translational errors}

- Mistranslation into the target language,

- Addition or omission.

\section{b. Linguistic errors}

- Relative pronouns and relative adverbs,

- Reducing relative clauses,

- Punctuation,

- Tense and conjugation,

- Word choice,

- The use of articles,

- Prepositions,

- Spelling,

- Singular and plural forms.

\section{Methodology}

This research was designed as a descriptive one with a combination of qualitative and quantitative approaches. The participants were 60 English-majored juniors, who were delivered the test papers to investigate problems resulting from Vietnamese-English translation of relative clauses. In addition, to make the research more specific and objective, interview questions were used to collect information about attitudes towards translation skill from 2 experienced teachers and 10 students. 


\section{Results and Discussion}

\subsection{Results from test papers}

A Vietnamese-English translation test was delivered to 60 participants, and 60 test responses were collected for data analysis. The researchers studied each response carefully to identify the participants' errors in translating sentences with relative clauses. The errors in translation of sentences with relative clauses were investigated via an eleven-item test (part 1: 7 items, part 2: 4 items). The responses were not scored either right or wrong or in terms of degree of correctness. Instead, the responses were analyzed to determine common errors that quantitatively characterized the test responses.

The responses from test papers were analyzed and divided into 2 parts based on the test paper's structure to clarify the problems in translation from Vietnamese to English with relative clauses.

\section{Part 1}

Table 1: The number and percentage of students'

incorrect Vietnamese-English translations with relative clauses

\begin{tabular}{|l|c|c|}
\hline & Number of sentences & Percentage (\%) \\
\hline Correct sentences & 173 & 41.19 \\
\hline Incomplete sentences & 35 & 8.33 \\
\hline Incorrect sentences & 212 & 50.48 \\
\hline Total & $\mathbf{4 2 0}$ & $\mathbf{1 0 0}$ \\
\hline
\end{tabular}

As can be seen from Table 1,41.19\% of sentences made by students were correct and $50.48 \%$ were incorrect. Incomplete sentences accounted for $8.33 \%$. Concerning this case, $1.90 \%$ of the sentences were not given with full translation and up to $6.43 \%$ of the sentences were not translated into relative clauses. This result showed that students faced difficulties when they translated with relative clauses.

The following table presents the frequencies of errors made by students from 212 incorrect sentences.

Table 2: Common errors of translating Vietnamese-English with relative clauses

\begin{tabular}{|l|c|c|}
\hline Types of errors & Number of errors & Percentage (\%) \\
\hline Mistranslation into the target language & 13 & 3.34 \\
\hline Addition or omission & 39 & 10.02 \\
\hline Relative pronouns and relative adverbs & 60 & 15.42 \\
\hline Punctuation & 15 & 3.86 \\
\hline Tense and conjugation & 28 & 7.20 \\
\hline Word choice & 51 & 13.11 \\
\hline Use of articles & 33 & 8.48 \\
\hline Prepositions & 29 & 7.46 \\
\hline Spelling & 43 & 11.05 \\
\hline Singular and plural forms & 78 & 20.05 \\
\hline Total & $\mathbf{3 8 9}$ & $\mathbf{1 0 0}$ \\
\hline
\end{tabular}




\section{Part 2}

Table 3: The number and percentage of students'

incorrect Vietnamese-English translation with reduced relative clauses

\begin{tabular}{|l|c|c|}
\hline & Number of sentences & Percentage (\%) \\
\hline Correct sentences & 94 & 39.17 \\
\hline Incomplete sentences & 35 & 14.58 \\
\hline Incorrect sentences & 111 & 46.25 \\
\hline Total & $\mathbf{2 4 0}$ & $\mathbf{1 0 0}$ \\
\hline
\end{tabular}

As clearly seen from the table above, $39.17 \%$ of sentences were correct and $46.25 \%$ were incorrect. In terms of incomplete sentences $(14.58 \%), 4.17 \%$ of the sentences were not translated completely and $10.42 \%$ of the sentences were not translated into reduced relative clauses. In brief, the result showed that students also had problems with reduced relative clauses.

The frequencies of errors from 111 incorrect sentences will be shown in the following table.

Table 4: Common errors of translating Vietnamese-English with reduced relative clauses

\begin{tabular}{|l|c|c|}
\hline Types of errors & Numbers of errors & Percentage (\%) \\
\hline Mistranslation into the target language & 3 & 2.54 \\
\hline Addition or omission & 14 & 11.86 \\
\hline Reducing relative clauses & 49 & 41.53 \\
\hline Punctuation & 15 & 12.71 \\
\hline Tense and conjugation & 12 & 10.17 \\
\hline Word choice & 5 & 4.24 \\
\hline Use of articles & 0 & 0 \\
\hline Prepositions & 3 & 2.54 \\
\hline Spelling & 0 & 0 \\
\hline Singular and plural forms & 17 & 14.41 \\
\hline Total & $\mathbf{1 1 8}$ & $\mathbf{1 0 0}$ \\
\hline
\end{tabular}

\subsection{Results from interview's questions}

\subsubsection{Results from students}

By and large, it can be deduced that vocabulary and grammar structures are two basic problems that most students have to confront in the translation process. Eight out of ten students said that they lacked the vocabulary to know the English equivalent in specific situations, especially academic words for translating a Vietnamese-English text. This was a serious problem confusing students. In addition, one hundred percent of the students conceded grammar errors are unavoidable. This was totally true in the light of the errors analyzed from test papers. There were 6 out of 10 students who were confused in choosing the appropriate tense in English. Sometimes, students could not recognize which tense should be used in a particular context. 
Concerning translating with relative clauses, according to the students' responses, most students encountered difficulties with relative pronouns when translating Vietnamese sentences into English relative clauses. Specifically, all students acknowledged that it was too hard for them to choose the correct relative pronouns and relative adverbs. Moreover, the others added that they had difficulty distinguishing between defining relative clauses and non-defining relative clauses. Therefore, putting commas in translated relative sentences properly also made students confused. Strikingly, one hundred percent of students claimed that reducing relative clauses were the biggest obstacle for them.

\subsubsection{Results from teachers}

Thanks to the results of interviewing teachers, the students' problems in translating with relative clauses became more obvious. Both of them said that poor grammar and lack of vocabulary were the common barriers in students' translation. Concerning the translation with relative clauses, they pointed that students faced difficulties in using relative pronouns and relative adverbs. Furthermore, they also stated that most of the students encountered difficulties when reducing relative clauses. This statement totally matched with the results from the test papers and the students' interview questions. One of them added that the major cause of these problems came from the difference between Vietnamese and English grammar. There are no relative clauses in Vietnamese, so students do not know how to translate them into English correctly.

\section{Conclusions}

The results from the tests and interviews proved that students could not produce correct translations because of the following problems. First, using relative pronouns and relative adverbs properly was a big challenge for most students. Students knew how to place relative pronouns and relative adverbs correctly, but they could not remember the usage of them. Concerning this problem, students should master the theory of relative clauses to avoid misusing relative pronouns or relative adverbs when translating Vietnamese into English. Another serious one was reducing relative clauses into relative phrases. In addition, the researchers realized that two of the biggest problems for students in written translation were vocabulary and grammar structures. Hence, students did not have enough vocabulary to transfer the full message from the source language into the target language, also causing errors relating to spelling or word choice. Due to the difference in grammar structures between Vietnamese and English, grammar errors were the most common errors.

\section{Acknowledgements}

The researchers are thankful to the teachers and students of Tay Do University for spending their priceless time participating in the study. 


\section{Conflicts of Interest Statement}

The authors whose names are listed immediately below certify that they have no conflicts of interest, authorship, and disclosures in publication. They confirm that this work is original and has not been published elsewhere, nor is it currently under consideration for publication elsewhere.

\section{About the Authors}

Thi Bao Dung Dang is currently a lecturer at Faculty of Linguistics and Literature, Tay Do University, Can Tho, Vietnam. She received her MA from Vitoria University, Australia. She has just completed her PhD program on comparative linguistics of Viet Nam National University Ho Chi Minh City, University of Social Sciences and Humanities (VNUHCM-USSH). Her research interests include linguistic features of Vietnamese and English political discourse. She has been teaching English for 20 years. She specializes in Cultures of English speaking countries, English for purposes and language skills.

Van Lanh Le is currently a lecturer at Faculty of Linguistics and Literature, Tay Do University, Can Tho, Vietnam. He received his MBA from Tay Do University and M.A from Can Tho University. He has been teaching English for 20 years. He specializes in Cultures of English speaking countries, English for purposes and language skills. At present, he is conducting some research on topics related to test-preparation teaching and collocations.

Van Si Vo is currently the deputy head of Scientific and International Relations Department of Tay Do University, Can Tho, Vietnam. He is also the co-founder of an English center which mainly delivers courses for kids and teenagers. He received his M.A of Principles and Teaching Methodology of English from Can Tho University. He has been teaching English for 19 years. He specializes in English communication and English for purposes. At present, he is interested in and conducting some research on topics related to blended learning (Moodle Platform).

Nhu Ngoc Hua is currently a lecturer at Faculty of Linguistics and Literature, Tay Do University, Can Tho, Vietnam. She received her MBA from Tay Do University and she is studying Master in Linguitics at Hutech. She has been teaching for 10 years. She specializes in English for Business Office, English for Sales and Purchasing. At present, she is conducting research related to using Social Media in language teaching and learning.

Phuong Nhu Nguyen has completed her BA program. Her desire is to become a teacher of English. She is now preparing for her MA program to make her dream come true. 


\section{References}

Al-Jarf, Reima Sado (2007). SVO Word Order Errors in English-Arabic Translation. META 52(2), 299-308.

Andrews, Avery (2007). Relative clauses. In Language typology and syntactic description. Vol. 2, Complex constructions. 2d ed. Edited by Timothy Shopen, 206-236. Cambridge, UK: Cambridge Univ. Press.

Ballard, K. (2007). The frameworks of English (2 ed.). New York: Palgrave.

Bayu Nugroho A. (2007) Meaning and Translation. Journal of English and Education 1(2).

Bui, T. K. P. (2018). Common structural errors in Vietnamese - English translation made by English majored Students at Duy Tan University.

Bui, T. B. \& Dang, X. T. (1997). Interpreting and Translation. Hanoi: Hanoi University of Foreign studies.

Bùi Ý (1980). Nhũung mẫu câu cơ bản Tiếng Anh. Nhà xuất bản Giáo Dục.

Catford, J. C. (1965). A Linguistic Theory of Translation. London: Longman.

Celce-Murcia, M. \& Larsen-Freeman, D. (1999). The grammar book. Boston: Heinle \& Heinle.

Đinh Văn Đức (2001). Ngữ pháp Tiếng Việt (Từ loại). Nhà xuất bản Đại học Quốc Gia Hà Nội.

Hồ Văn Hiệp-Ninh Hùng (2004). Văn phạm Anh ngũu thực hành. Nhà xuất bản Thống kê.

Lê, V. S. (2003). Translation and Grammar. Hanoi: Culture and Information Publishing House.

Mohaghegh, H. Zarandi, M. \& Shariati, M. (2011). Grammatical Errors produced by English majors: The Translation Task. Educational Research and Reviews, Vol. 6(16), pp 877-888.

Newmark, P. (1988). A text book of Translation. New York: Prentice Hall International.

Nguyen, V. P. (2018). Strategies used by English Interpretation and Translation-majored

Seniors to solve linguistic difficulties in English-Vietnamese Advertising Translation. Can Tho University Journal of Science, 54(5), 23-29.

Nguyen, T. H. T. \& Bui, T. H. T(2013). English Major Students' Difficulties and

Expectations in Learning Written Translation at Dong Thap University.

Nguyễn Khuê (2003). Ngũu pháp Tiếng Anh. Nhà xuất bản Đại học Sư phạm.

Nida, E. A. \& Taber, C. R. (1982). The Theory and Practice of Translation. Leiden: Brill.

Pojprasat. S. (2007). An analysis of Translation Errors made by Mattayomsuksa 6 Students.

Trieu, T. H. (2015). Vietnamese-English Translation Errors Made by Second Year Translation-Major Students: An Initial Step towards Enhancing Translation Standards. Tạp chí Khoa học ĐHQGHN: Nghiên cúu Nước ngoài, 31(1), 22-32.

Wongranu, P. (2017). Errors in Translation made by English major students: A study on types and causes. Kasetsart Journal of Social Sciences, 38(2), 117-12. 
Creative Commons licensing terms

Authors will retain the copyright of their published articles agreeing that a Creative Commons Attribution 4.0 International License (CC BY 4.0) terms will be applied to their work. Under the terms of this license, no permission is required from the author(s) or publisher for members of the community to copy, distribute, transmit or adapt the article content, providing a proper, prominent and unambiguous attribution to the authors in a manner that makes clear that the materials are being reused under permission of a Creative Commons License. Views, opinions, and conclusions expressed in this research article are views, opinions and conclusions of the author(s). Open Access Publishing Group and European Journal of English Language Teaching shall not be responsible or answerable for any loss, damage or liability caused in relation to/arising out of conflict of interests, copyright violations and inappropriate or inaccurate use of any kind content related or integrated on the research work. All the published works are meeting the Open Access Publishing requirements and can be freely accessed, shared, modified, distributed and used in educational, commercial and non-commercial purposes under a Creative Commons Attribution 4.0 International License (CC BY 4.0). 